\title{
A Study of Themes and Symbols in Group Sandplay Therapy of Rohingya Refugee Children in Malaysia
}

\author{
SeHwa Lee* \\ Mikyung Jang**
}

\begin{abstract}
$<$ Abstract $>$
This study analyzed the common themes and symbols expressed in group sandpictures of Rohingya refugees children who had fled from racial and religion oppressions in Myanmar and settled in Malaysia. A total of eight children who attended an international refugee school located in Kuala Lumpur, Malaysia participated in the study. The school is under the auspice of the UN Refugee Agency. These children were given three group sandplay sessions of 90 minutes over a period of two weeks. The participants' sandpictures and comments during therapy were interpreted through an analytical psychological approach, after which the collected data was classified according to their similarities. Then the data was narrowed down, and themes that often arose in the sandpictures were categorized. As a result, five common themes were observed: destruction and death, ceaseless fighting, family members at risk, survival of the boat people, and the first step toward a normal life. The participants represented traumas they received, from the process of violent repression, evacuation, and adaptation to Malaysia, through direct linguistic expressions together with destructive and endless fighting sandpicture scenes. This study provided them with an opportunity to express their traumas and psychological distress under a trust-based relationship amongst the group members and to recognize the possibility that they could bring changes into their lives.
\end{abstract}

Keywords : Rohingya refugee children, group sandplay therapy, symbols, themes, boat people

\footnotetext{
* Ph.D. student, Child Welfare Department at Graduate School of Namseoul University (gginmandu@hanmail.net)

** Professor, Namseoul University (jangmiky@hotmail.com)
} 
Journal of Symbols \& Sandplay Therapy, Vol.9 No.1.

\section{I . Introduction}

In September 2017, a vessel carrying Rohingyas escaping Myanmar capsized, killing at least 10 children and 4 women (Iseoul, 2017). Tens of thousands of Rohingya Muslims, who are being prosecuted for their religion, are fleeing to Bangladesh, Malaysia and other neighboring Muslim countries. The Rohingya people make up 2.5\% (1.3 million) of Myanmar's population. The conflict between the dominant Bamas and the Rohingyas has continued since the late nineteenth century (Park, 2017). In 1982, the $\mathrm{Ne}$ Win government of Myanmar amended the civil law so that no citizenship would be granted to the one million Rohingyas, making them stateless even until today (Lee, 2015; Human Right Watch, 2013).

Since the violent outbreak between the Buddhists and the Rohingyas in Rakhine state in 2012, millions of Rohingyas have fled for their lives to neighboring countries such as Bangladesh, Indonesia, Malaysia and Thailand. But because these nations refused to accept the migrants, the Rohingyas became Asia's new "boat people" who remain stranded at sea. In February 2016, 44,870 Rohingyas from Myanmar were registered with UNHCR in Malaysia (UNHCR, 2016). Many of the Rohingyas who arrived in Malaysia were struggling with mental illnesses such as anxiety, sleep disorders, severe PTSD and suicide attempt (Equal Rights Trust, 2010).

These refugees repeatedly experience serious traumas beyond their control, which is attributable to atrocious persecution that accompanied violence, abuse, loss and unemployment. As a result, they manifest anxiety, depression, severe anger, sleep disorder, suicidal ideation, memory disturbances and attention deficit as well as somatization symptoms such as headache and neck pain (Alayarian, 2007/2011; Ehntholt \& Yule, 2006). Among them, children are more vulnerable to serious trauma, which is caused largely by three reasons: (1) experience of war and conflict, direct and indirect violence, loss of family and friends in their home country, (2) separation from parents and accidents during the course of escape, and (3) adaptation to a new environment (Fazel \& Stein, 2002). These events can lead to not only physical health problems but also psychological problems for young children. Their psycho-social stress is usually manifested as eating disorders, sleep disorder, regressive behaviors such as separation anxiety, guilt, somatization, intrusion upon others, fear of family members and the future, behavior 
problems like screaming, crying or destroying objects, and hyperactivity. In case of adolescents, it could be substance abuse, crime and violence, (Maršanić, Franić \& Ćurković, 2017), and adolescents can be exposed to drug abuse, crime and violence. Depression is also sometimes associated with traumatic experiences (Thabet, Abed, \& Vostanis, 2004).

Refugees experience multiple traumas and stressful events during the process of settling into a new environment. Refugee camps do not guarantee a safe haven because camps are often unsanitary and violence may create dangerous conditions in the camp, compounding already existing trauma and psychological problems (Bemak \& Chung, 2017). Children, who depend entirely on their guardians for survival, are affected by the guardians' mental health status (Panter-Brick, Grimon, \& Eggerman, 2014). According to the study of Chung (2001), the groups of refugees at higher risk for developing more serious mental health problems and trauma are older refugees, unaccompanied minors, single men younger than 21 years who lack familial and social support, women who are widowed and women and girls who were victims of rape and sexual assault during displacement.

Sandplay therapy is a psychotherapy technique combining sand and play, where sand, water and figures are placed inside a sandtray to create various images. Children can naturally express their experiences and emotions through play rather than through words. Through sandplay therapy, the traumatic experiences of a client that could not be described verbally can be expressed through images and bodily sensations (Jang, 2017). In addition, a "group" environment is a dynamic setting that seeks changes through mutual interaction (Kim \& Jeong, 2002). Therefore, compared to individual therapy, group therapy can facilitate the practice of social skills, the experiences of catharsis and voluntariness, and the development of a therapeutic relationship among children (Seo, 2007).

Therefore, sandplay therapy enables refugee children to express their emotions, which cannot be expressed verbally, in a nonverbal manner (Wirtz, 2009). The symbolic images of "here and now" make it possible for the clients to think about their experiences and verbalize it (Mancia, 2007). A group sandplay therapy also enables one to speak about his or her traumatic experiences and difficulties through nonverbal expressions, within the trust relationship he or she has formed with the therapist and the other people in the group. This 
Journal of Symbols \& Sandplay Therapy, Vol.9 No.1.

psychotherapeutic approach is appropriate for Rohingya refugee children when taking into consideration their inner and cultural resources. Sandplay therapy can help them overcome psychological difficulties by externalizing their trauma experience.

The purpose of this study was to provide group sandplay therapy to Rohingya refugees children living in Malaysia so as to give them the opportunity to express their inner world, and therefore help them resolve and overcome their traumas and inner conflicts. To this end, this study analyzed the common themes and symbols expressed in the sandpictures of the Rohingya refugee children.

\section{П. Research Method}

\section{A. Participants}

This study administered group sandplay therapy to Rohingya refugee children living in Kuala Lumpur, Malaysia where there is a UNHCR office. Among children aged 11 to 14 who are enrolled in an international refugee school under the auspice of UNHCR, those who scored 17 or higher outcome measures for PTSD (CRIES-13) were selected to participate in the study. A total of 8 children, 4 boys and 4 girls, took part in the study. The study obtained informed consent from the participants and their guardians, about the program itself and about videotaping therapy sessions

All participants were Muslim, and the process of their escape from Myanmar was the same: The father first escaped to Malaysia to earn money to cover the cost of taking his family out of Myanmar. In other words, these children escaped to Malaysia after some period of family separation. When the father gathered enough money, those who stayed behind fled from Myanmar on a boat with the help of brokers. The general personal information of the participants is shown in Table 1: 
Table 1. General personal information of research participants

\begin{tabular}{|c|c|c|c|c|}
\hline Participants & Gender & Age & $\begin{array}{c}\text { CRIES-13 } \\
\text { score }\end{array}$ & Important facts \\
\hline Child A & Male & 11 & 32 & $\begin{array}{l}\text { Born in Malaysia. Father is a Rohingya and mother is a Myanmar } \\
\text { Muslim. Reported that his second older brother died while fleeing } \\
\text { to Malaysia. }\end{array}$ \\
\hline Child B & Male & 12 & 30 & $\begin{array}{l}\text { Entered Malaysia at the age of } 7 \text { after being stranded on a boat } \\
\text { for } 7 \text { months. Was exposed to the violence of the Myanmar } \\
\text { government against Rohingyas. }\end{array}$ \\
\hline Child C & Male & 12 & 32 & $\begin{array}{l}\text { Father is a Myanmar Muslim and mother is a Rohingya. Entered } \\
\text { Malaysia at the age of } 5 \text { via Thailand after being stranded on a } \\
\text { boat for a month. Witnessed people being chased or shot to death } \\
\text { by soldiers during the course of his escape. }\end{array}$ \\
\hline Child D & Male & 14 & 27 & Fled to Malaysia on a boat 3 years ago. \\
\hline Child E & Female & 11 & 33 & $\begin{array}{l}\text { Entered Malaysia } 5 \text { years ago after being stranded on a boat for } 7 \\
\text { months. Witnessed two women, who died of starvation, being } \\
\text { thrown out of the boat by other men. Her maternal grandfather } \\
\text { died of heart attack on the boat. When the family arrived in } \\
\text { Thailand, the broker sent his maternal grandmother and aunt back } \\
\text { to Myanmar because they didn't have enough money. }\end{array}$ \\
\hline Child F & Female & 11 & 33 & Fled to Malaysia on a boat 3 years ago with her pregnant mother. \\
\hline Child G & Female & 12 & 17 & $\begin{array}{l}\text { Father is a Rohingya and mother is a Myanmar Muslim. Fled to } \\
\text { Malaysia on a boat } 5 \text { years ago with her mother and her older } \\
\text { sister. }\end{array}$ \\
\hline Child H & Female & 12 & 31 & $\begin{array}{l}\text { Father is a Rohingya and mother is a Myanmar Muslim. Entered } \\
\text { Malaysia at the age of } 4 \text { after being stranded on a boat for } 2 \\
\text { months. }\end{array}$ \\
\hline
\end{tabular}

\section{B. Research Process}

Taking into consideration of the Islamic culture, this study divided the two groups into different genders: One group was comprised of 4 boys and the other group was comprised of 4 girls. A total of three sessions were given to each group for 90 minutes over the period 
Journal of Symbols \& Sandplay Therapy, Vol.9 No.1.

of 2 weeks in February, 2018. The date of therapy was set according to the time that the children were available. The sandplay therapy was non-directive, so as to provide the "free and protected space" as emphasized by Dora Kalff. Participants in each group were paired into twos and took turns to create individual sandpictures.

The Children's Revised Impact of Event Scale (CRIES-13) was administered during the first session in order to assess the posttraumatic stress level of the participants. CRIES-13 was derived from the Impact of Event Scale (IES) for adults. It has a total pf 13 items, which are rated on a 4-point Likert-type scale. Scores range from 0 to 65 , with higher scores indicating higher severity of PTSD. A cut-off score of 17 refers to a high possibility of PTSD diagnosis and a cut-off score of 30 would identify a child with PTSD (Deeba, Rapee, \& Prvan, 2014). In addition, to minimize the problem of language barrier, the scales used were written in English or in the Myanmar language. The researchers also conducted therapy together with a local coordinator or an interpreter to further minimize cultural and linguistic differences. CRIES-13 revealed that 6 participants could be diagnosed with PTSD (CRIES-13 Total $\geq 30$ ). Among them, some belonged to the high-intrusion group ( $\mathrm{In}=19$ ).

\section{Data Analysis}

Before the start of the group sandplay therapy program, the researchers obtained personal information of the participants such as their background, chief complaints and many others through a one-on-one meeting with the participants as well as meeting with their school teachers. And while the program was ongoing, the researchers wrote down different verbal and nonverbal expressions made by the participants and also took photographs and videos so as to observe their behaviors and collect visual materials.

The following analytic procedure was used to identify the common themes in sandpictures of all participants. The sandpictures and the verbal stories were interpreted in the framework of Jungian analytical psychology; the elements especially subject to analysis were symbolic images related to myths, religions and fairy tales that represented both the collective and personal unconscious. Later, all data collected was combined, from which meaningful contents were recorded; the abstract research themes were funneled into more specific contents 
(Bogdan \& Biklen, 2006). Hence themes that were common to the sandpictures of Rohingya refugee children in the program were categorized.

This study sought to exclude any premise or preconceptions on the part of the researcher and remain objective throughout the entire process of qualitative analysis, from collecting data to identifying the common themes. And as a means to increase the validity of its findings, the study used the triangulation technique that took into consideration (1) interviews with the participants, (2) observed behaviors and (3) the content and the symbols in sandpictures. Afterwards, the findings were reexamined by three peer sandplay therapists

\section{Research Results}

The themes in the group sandpictures of Rohingya refugee children living in Malaysia were divided into five categories. The sandpicture scenes and symbols that appeared in each category are as follows:

Table 2. Themes and the details of the sandpictures created by Rohingya refugee children

\begin{tabular}{|c|c|}
\hline Theme & Details \\
\hline $\begin{array}{l}\text { Destruction } \\
\text { and death }\end{array}$ & $\begin{array}{l}\text { Armed police and soldiers, a king/queen holding a sword, a snake attacking people, } \\
\text { death caused by an attacking tiger or a car accident }\end{array}$ \\
\hline Ceaseless fights & $\begin{array}{l}\text { A snake devouring people vs. a fighting cowboy; a land of the soldiers shooting } \\
\text { guns and cannons vs. a land without weapons; the good team of the Green Hero } \\
\text { vs. a bad team of the king/queen and soldiers; a ferocious tiger vs. a defiant boy }\end{array}$ \\
\hline $\begin{array}{l}\text { Family members } \\
\text { at risk }\end{array}$ & $\begin{array}{l}\text { Rescuing of the kidnapped sibling, people hunting runaway animals, children } \\
\text { without parents }\end{array}$ \\
\hline $\begin{array}{l}\text { Survival of the } \\
\text { boat people }\end{array}$ & $\begin{array}{l}\text { Soldiers attacking people on a boat, hunting for food and the dangers at sea, } \\
\text { running away from border guards }\end{array}$ \\
\hline $\begin{array}{l}\text { The first step } \\
\text { toward a normal life }\end{array}$ & Fences, safe space, a car that can travel anywhere, school, a person selling items \\
\hline
\end{tabular}


Journal of Symbols \& Sandplay Therapy, Vol.9 No.1.

\section{A. Destruction and Death}

Rohingya refugee boys depicted police officers and soldiers not as guardians but as aggressors and destroyers; they were pointing guns at people on a boat or attacking animals. Two figures that often appeared in sandpictures were a queen holding a sword and a king wearing robe-like clothing. The queen figure reminds of us of the current Myanmar leader Aung San Suu Kyi in traditional clothing. Many Rohingyas and Myanmar Muslims were killed or assaulted by armed soldiers and police officers at the bidding of the Myanmar government, and young children were exposed to the violence through pictures and videos. The police officers, soldiers, queen and king represent destruction but at the same time suggest, at a psychological level, that protection and order needs to be restored in these children's lives.

Many of Rohingya refugee girls expressed death in an indirect manner, through a snack or a tiger attacking people or a car accident. Their traumatic experiences, which brought overwhelming fear and anxiety in their life, and the resulting stress and anger were symbolized by animals like snakes and tigers. From the viewpoint of neurobiology, they represent primal fear (Jang, 2017). The children used different symbols to externalize their traumatic experiences, which were fragmented in their inner world, through their sandpictures. In doing so, they are able to control the uncontrollable trauma within their own world, which is an attempt to recover their strength and sense of control (Gill, 2006; Malchiodi, 2003).

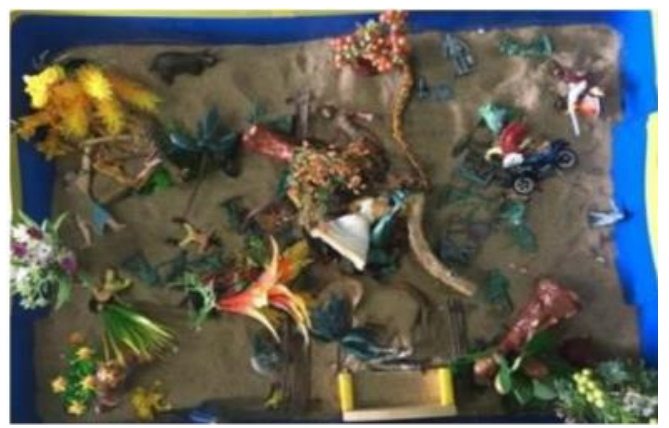

Fig. 1. Sandpicture of child B (session 1) 
In this sandpicture, soldiers with a gun or a grenade, a king throwing a lightning bolt (Zeus) and a queen holding a sword while riding on a motorbike are attacking an aboriginal person, an ancient person and animals. The armed soldiers and the king are destroying the forest and killing the animals and the people. The center area of the tray is the battlefield. In fact, the state of Rakhine in Myanmar, which is home to the Rohingya people, is a place where there were frequent outbreaks of a war between Pakistan and India in the past. Today, it is seated between Bangladesh, which became independent from Pakistan, and India.
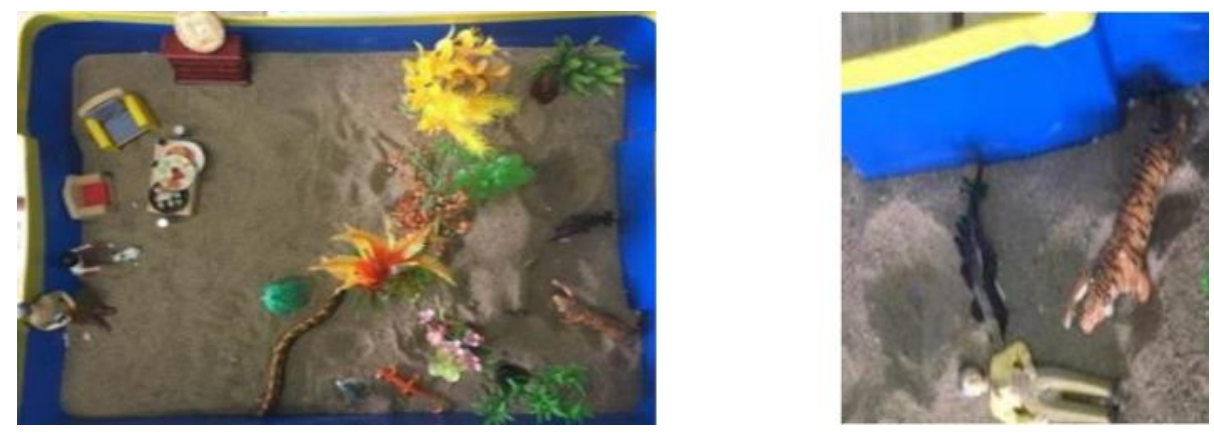

Fig. 2. Sandpicture of child $H$ (session 1)

The mother of the little girl figure died from an attack by the tiger, which has ones of its front paws raised. The dear mother is buried in the near right quadrant of the sandtray. Next to the dead mother is a small dinosaur that lost its mother.

\section{B. Ceaseless Fights}

Children who are trapped inside their traumas tend to see the world through the lens of trauma, which means that they do not comprehend their surrounding situations in an objective manner. They do not have the psychological flexibility that allows them to picture new possibilities through imagination. This is related to the level of cognition with regards to sensations arising from the body; lower levels of interoception indicate lowers levels of control in life (Levine, 2008; Ogden, Minton, \& Pain, 2006). Traumatic events like religious oppression, 
Journal of Symbols \& Sandplay Therapy, Vol.9 No.1.

ceaseless fight between tribes, violence and death, which is what people from Myanmar experienced, deprive them of their imagination, eat away the comfort of the inner world, and cause psychological and physical health problems. Fights or conflicts in the sandpictures of refugee children also represent not only their traumatic experiences but also their attempt to control and deal with them. The theme of fighting or conflict in a child's sandpicture indicates, from a psychological level, tension and the direction in which the child's inner energy is flowing. According to Jung, unbearable conflict is evidence that life is moving in the right direction, and the conflict can release the energy that had been bound by the self-control function of the psyche and the tension. Then this energy can be used in a creative way to enhance life (Jang, 2017).

Then we observed a struggle against those traumatic experiences, or an attempt to recover the ego function, in the sandpictures in the form of: A snake devouring people vs. a fighting cowboy; a land of the soldiers shooting guns and cannons vs. a land without weapons; the good team of the Green Hero vs. a bad team of the king/queen and soldiers; a ferocious tiger vs. a defiant boy. There was also a distinction of space through the appearance of mounds, walls and fences. These structures or objects seemed to create a boundary between inside and outside, good and evil and the fighting domain and the safe domain, thereby differentiating and controlling them.

Like the picture below, fences or walls were either collapsed or did not appear at all in the very first sandpictures. But as therapy progressed, the fences became sturdier and there were more literal attempts of control. There was also the appearance of groups and heroes that resisted the evil forces.

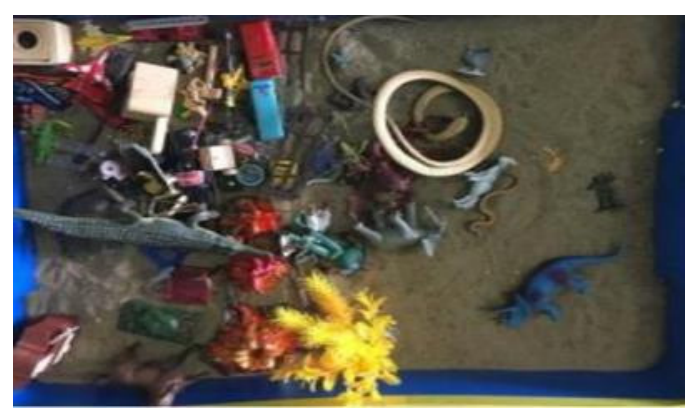

Fig. 3. Sandpicture of child A (session 2) 
The right side of this sandpicture is a land of the ordinary people while the left side is the land of the queen, king and soldiers. When those from the left side invaded the right side, the fences collapsed and the volcano erupted. The Green Hero and the animals are fighting to protect the ordinary people. The color green is a symbol of hope, happiness and transformation, and is considered sacred in Islam as it is the color representing Prophet Mohammed (Cooper, 1978/2012). The Green Hero in child A's picture is a good, sacred hero who resists against evil forces.

\section{Family Members at Risk}

Beiser (2009) explained that refugees are often exposed to direct combat, being close to death, lacking food or water, physical threat, forced separations, and murder of family and friends. The process of escape can bring about confusion in the refugees' lives. In most cases, the father first escapes to Malaysia to earn money, and then pays a broker to take the rest of the family out of Myanmar. During this process, the children experienced anxiety, tension, and fear of death. Every single participant of this study created a sandpicture where the family becomes separated and faces risks. Their sandpictures showed the process of evacuation, the rescue of a kidnapped sibling, animal hunting, and children without parents.

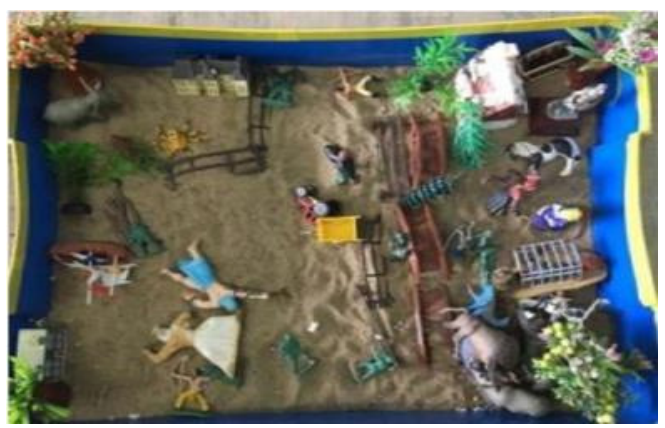

Fig. 4. Sandpicture of child B (session 2)

The sandpicture above illustrates the rescue of a kidnapped sibling. The leader of the bad team, which is on the right side of the tray, abducted the younger brother of the leader 
Journal of Symbols \& Sandplay Therapy, Vol.9 No.1.

of the good team. Some members of the good team went to rescue the abducted boy by riding on a boat and crossing a bridge. The child explained that although the bad team attacks the rescuers when they are on the boat and the bridge, they will be able to rescue the boy and live with him again.

Child C said, in an agitated voice, "The dad is surrounded by police officers and gets his money taken. The girl freaks out and runs to where her dad's brothers are. The dad has to come back to his family; I'm worried."

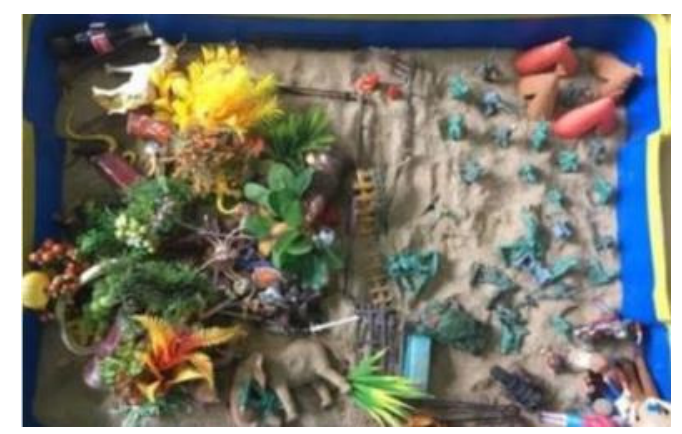

Fig. 5. Sandpicture of child C (session 3)

\section{Survival of the Boat People}

All participants but one traveled to Malaysia on a boat. During the trip, they faced serious risks to their survival; they witnessed people starving to death, nearly dying from downing, being threatened by guns or tanks. Some who went to Thailand before arriving in Malaysia had to abandon the anchored boat and hide inside the nearby forest to escape immediate danger. These children spoke in a shrill voice when talking about the boat inside their sandpictures, with their hands trembling or continuously touching the sand or leaving fingerprints on the sand. Especially when referring to boats in sandy scenes, the voices seemed to be excited, or shaking hands, constantly touching the sand, or throwing handprints. This particular theme was expressed through scenes depicting soldiers attacking people on a boat, people hunting animals for survival, dangers at sea and people fleeing from border guards. The 
boat that refugees traveled on is reminiscent of Noah's Ark; it symbolizes a rescue boat traveling across the sea of death, the safe haven, and the bridge that connects to a new world.

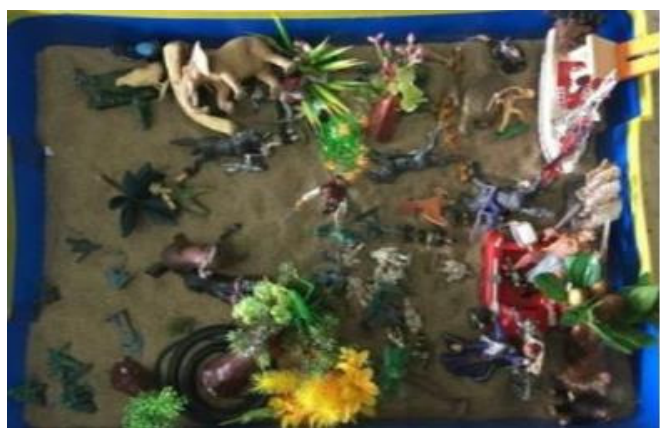

Fig. 6. Sandpicture of child C (session 2)

The left half of the tray is the "land of the soldiers," and the right side of the tray can be accessed by a boat. People living in the center area of the tray, where trees grow, are trying to leave the area on a boat, but soldiers are firing guns and cannons at them. People on board are dying because they do not have weapons to fight back. The magician is coming to protect the people on board. In fact, Child C mentioned, in an excited and agitated voice, that he saw people being chased or shot dead by soldiers during his escape to Malaysia.

The sandpicture below represent a client's experience of the escape. The right side represents the client's house in Myanmar; there are food and water inside the brown box. The people in Myanmar go to meet the broker at the center area, and then head for Thailand, which is on the left side of the tray, en route to Malaysia on a boat. The people hide in the

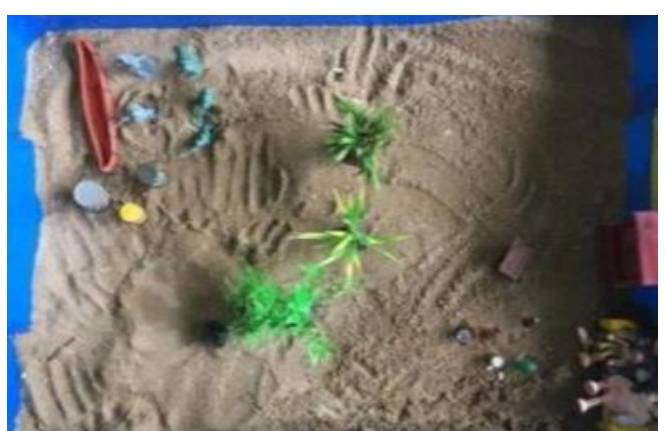

Fig. 7. Sandpicture of child G (session 2) 


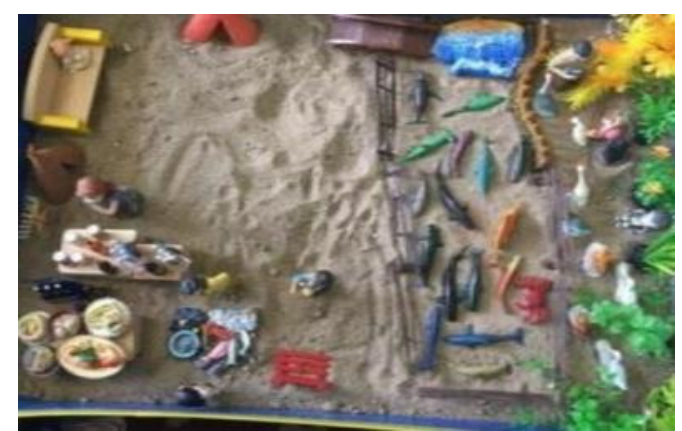

Fig. 8. Sandpicture of child H (session 3)

forest to avoid armed Thai soldiers, and then again depart for Malaysia while only having water to drink on the way. The handprints on the sand convey the urgency of the situation.

Child $\mathrm{H}$ was stranded at sea for 7 months before coming to Malaysia, during which she faced many life-threatening situations like falling into the sea and being rescued by her mother, and witnessing other people on the boat starving to death. The left and right sides of her sandpicture shown above depict opposite situations: The right side is occupied with zombies while the left side is occupied with people who are eating food in everyday reality. The fenced center area is a sea filled with sharks and fish, representing the dangerous circumstances she had been exposed for those 7 months. The child initially put a waterfall figure instead of a wave figure in the center area and talked about the dangerous moments that she and the rest of the people on the boat had experienced. Then she said, "I've never talked about this [experience], but now it's okay for me to talk about it. Thank you for listening to my story," after which she replaced the waterfall with a calm wave. Her traumatic experience is no longer a negative, destructive and devouring wave but a gentle one.

\section{E. The First Step Toward a Normal Life}

Even after reuniting with their families, refugees continue to suffer trauma and stress from language difficulties, food shortages, poor living conditions and lack of medical care and emotional support (Strekalova \& Hoot, 2008). If we view resettlement as a means of psychological compensation for a chaotic living environment, economic difficulties and anxiety 
about the unpredictable future, their hopes of a safe place and a home of their own to overcome them is, in a way, natural. These people fled their homeland on a boat in the hopes that they could settle in a new world free of oppression, mass violence and abuse. As they no longer had to be anxious about armed soldiers in their new, safe environment, the refugees began their attempts to return to normal life. These attempts were represented as fences, symbols of order and boundary, a safe space, a car that can travel anywhere, and a person selling items in the sandpictures.

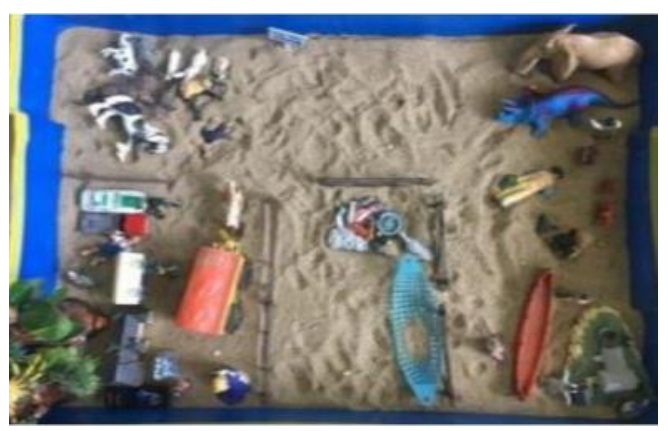

Fig. 9. Sandpicture of child D (session 3)

Fences divide the sandtray space into different segments. In the left space is a house, a school, and someone washing a car. People came to the left area from a small island on the right via a boat. For refugee children, the school is a place where they find safety, meet their peers, and learn a new language to adapt to their new living environment. Language is an important factor for settling and adapting to the new world.

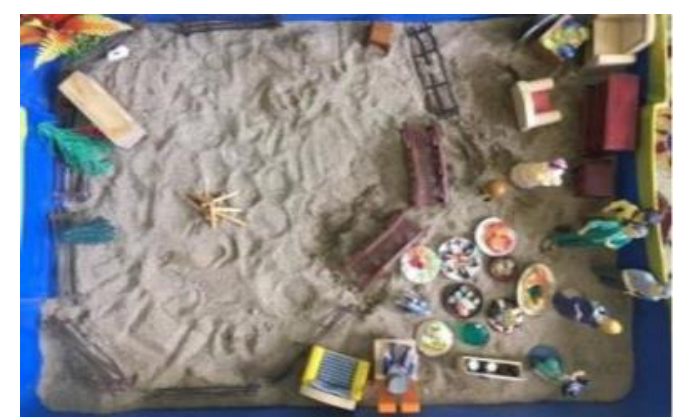

Fig. 10. Sandpicture of child G (session 3) 
Journal of Symbols \& Sandplay Therapy, Vol.9 No.1.

On the right side of the sandpicture above is a family having a party; the area is full of people, furniture and food. On the left side is a place with a bonfire where people can have conversations; the area is somewhat barren compared to the area on the right. The child who made this picture wished to be able to continue doing the things that she was able to do in the past. Near the center area, we see two bridges that connect the two sides.

\section{Conclusion}

The objective of this study was to analyze the themes and symbols evident in the sandpictures of Rohingya refugee children, who fled from their native country and are the process of resettling in Malaysia, created during group sandplay therapy.

Participants of this study involved 8 Rohingya refugee children living in Malaysia. These children fled from the brutality of religious persecution by the Myanmar government. All of them were Muslims. Except for one child, everyone witnessed abuse, violence, injuries and deaths during the escape.

There were five common themes in the sandpictures of these children: "Destruction and death," "ceaseless fights," "family members at risk," "survival of the boat people," and "the first step toward a normal life." Such a finding supports the claims of related studies that children engage in repetitive play involving trauma-related themes (Lee, 2016; APA, 2013; Eth, 2001). Moreover, this study showed that sandplay therapy is an adequate means of intervention for children with trauma, allowing them to represent their experiences in a nonverbal manner and explore their inner world by externalizing the traumatic events (Doyle \& Magor-Blatch, 2017). In addition, there were differences between male and female children in the way they expressed the traumatic event, which is perhaps attributable to the Islam culture and the patriarchal family system in their home: Boys reproduced their stories directly in the sandtray, whereas girls represented their stories indirectly, in the form of an attack from a tiger or a snake. This suggests the need for a future study on how cultural factors may influence the way refugee children express their traumatic experience in sandplay therapy (Jang, 2017; Maharatta et al., 2017; Sharma et al., 2010). Through sandplay, participants were able to 
explore their unrecognized desires and needs. And because the therapy helped them reactivate their imaginations, they were able to have hope about returning to their ordinary life.

As therapy progressed, small changes were observed in the facial expressions and attitudes of the participants. In the first session, some did not speak, did not meet eyes with the therapist, tried to hit other participants, or shook their legs or hands. But as time passed, they emulated the therapists' attitude of attentive listening or speaking in a gentle voice. They also became more enthusiastic about the therapy and hence were more open to sharing their stories with the group and more focused on listening to other people in the group. The children reported that they were able to focus on themselves by sharing their psychological difficulties and pain, and that they realized what it is like to share warmth with other people.

This study intended to understand the psychological difficulties experienced by refugee children who faced a life-threatening traumatic event. Using their senses, they expressed their inner world in the sandtray, which gave them the opportunity to work in the here and now through therapeutic distance. In addition, considering that trauma and stress makes the victims keep a distance from people in terms of interpersonal relationships, this study allowed the children experience interpersonal relationships in the context of a group therapy. This study is meaningful as it categorized common themes that appeared in sandpictures of Rohingya refugee children who fled Myanmar and are living in Malaysia and allowed these children to differentiate their emotions from others' and become aware of the possibility to transform. Furthermore, the study provides a framework for future studies on traumas of refugee children, and informs the international community of the urgent needs of refugee children for psychological therapy. However, due to the small number of study participants and a rather short research period, the findings of this study cannot be generalized for all Rohingya refugee children living in Malaysia. Future studies would have to also take into consideration their personal development history as well as family history. 
Journal of Symbols \& Sandplay Therapy, Vol.9 No.1.

\section{References}

Kim, C-K., Chung, Y-J. (2002). Group counseling. Seoul: Hakjisa.

Park, S-I. (2017). "Rohingya escaping Myanmar from massacre ... Muslims are bustling with the oppression of Muslims". hankung. Retrieved from http://news.hankyung.com/article/ 2017 091024591 (accessed 10, Sep 2017).

Seo, M-Y. (2007). The Study on Psycho and Social Adaptation of Children in Divorced Family by Group Play Therapy - Focusing on self-esteem, emotional maladjustment, and recognition of divorce -. Graduate school dissertation, Hanyang University.

Iseoul. (2017). "Boat shipwrecked by Rohingya ... At least 13 people died". Retrieved from http://www.seoul.co.kr/news/newsView.php?id=20170928500220 (accessed 28, Sep 2017).

Lee, S-I. (2015). The Tragedy of the Rohingya: Causes of Conflict and Persecution from a Historical Perspective. Graduate school dissertation, Changwon National University.

Lee, Y-A. (2016). An analysis of posttraumatic play characteristics of an abused child in play therapy. Korean Journal of Play Therapy, 19(2), 335-362.

Jang, M-K. (2017a). Analytical Psychology Sandplay Therapy. Seoul: Hakjisa.

Jang, M-K. (2017b). Archetypal Symbolism in the Recovery Process from Natural Disaster: Sandplay Therapy of Nepal Earthquake Adolescent Survivors. Journal of Symbols \& Sandplay Therapy, 8(2), 1-22.

Alayarian, A. (2007). Resilience, Suffering, and Creativity-The work of the Refugee Therapy Centre. London: Karnacbooks. (Trans. into Korean in 2011).

American Psychiatric Association (2013). Diagnostic and statistical manual of mental disorders (5th ed.). Washington D. C., London England: American Psychiatric Publishing.

Beiser, M. (2009). Resettling refugees and safeguarding their mental health: Lessons learned from the Canadian refugee resettlement project. Transcultural Psychiatry, 46, 539-583.

Bemak, F., \& Chung, R. C. Y. (2017). Refugee trauma: Culturally responsive counseling interventions. Journal of Counseling \& Development, 95(3), 299-308.

Bogdan, R. C., \& Biklen, S. K. (2006). Qualitative research in (validation) and qualitative (inquiry) studies. In Qualitative research for education: An introduction to theory and methods (5th ed.). Boston: Allyn \& Bacon. 
Chung, R. C. Y. (2001). Psychosocial adjustment of Cambodian refugee women: Implications for mental health counseling. Journal of Mental Health Counseling, 23(2), 115-126.

Cooper, J. C. (1978/2012). An illustrated encyclopaedia of traditional symbols. New York: Thames \& Hudson. (Trans. into Korean in 2012).

Deeba, F., Rapee, R. M., \& Prvan T. (2014). Psychometric properties of the children's Revised Impact of Events Scale (CRIES) with Bangladesh children and adolescents. PeerJ 2:e536.

Doyle, K., \& Magor-Blatch, L. E. (2017). "Even adults need to play": Sandplay therapy with an adult survivor of childhood abuse. International Journal of Play Therapy, 26(1), 12-22.

Ehntholt, K. A., \& Yule, W. (2006). Practitioner review: Assessment and treatment of refugee children and adolescents who have experienced war related trauma. Journal of Child Psychology and Psychiatry, 47(12), 1197-1210.

Eth, S. (2001). Introduction: Childhood trauma in perspective. In S Eth (Ed.), PTSD in children and adolescents. Washington, DC: American Psychiatric Publishing.

Equal Rights Trust. (2010). Trapped in a cycle of flight: Stateless Robingya in Malaysia. London: The Equal Rights Trust.

Fazel, M., \& Stein, A. (2002). The mental health of refugee children. Archives of disease in childhood, 87(5), 366-370.

Gil, E. (2006). Helping abused and traumatized children: Integrating directive and nondirective approaches. New York: Guilford Press.

Human Right Watch (2013). "Burma: Rohingya Muslims Face Humanitarian Crisis". Retrieved from https:/www.hrw.org/news/2013/03/26/burma-rohingya-muslims-face-humanitarian-crisis (accessed 06, Oct 2017).

Levin, P. A. (2008). Healing trauma: A pioneering program for restoring the wisdom of your body. Cal-Berkeley: North Atlantic Books.

Maharatta, K., Samuel, R., Sharma, P., Dixit, L., \& Shrestha, B. R. (2017). Suicide burden and prevention in Nepal: The need for a national strategy. WHO South-East Asia journal of Public Health, 6(1), 45-49.

Mancia, M. (2007). Feeling the words: Neuropsychoanalytic understanding of memory and the unconscious. London/New York: Routledge. 
Journal of Symbols \& Sandplay Therapy, Vol.9 No.1.

Malchiodi, C. (2003). Effective practice with traumatized cbildren: Ethics, evidence, and cultural sensitivity. In C. Malchiodi (Ed.), Creative interventions with traumatized children. New York: Guilford Press.

Maršanić, V. B., Franić, T., \& Curković, K. D. (2017). Mental health issues of refugee children: lessons from Croatia. European Child \& Adolescent Psychiatry, 26(3), 377-381.

Ogden, P., Minton, K., \& Pain, C. (2006). Trauma and the Body: A sensorimotor approach to psychotherapy. New York: WW Norton \& Company.

Panter-Brick, C., Grimon, MP., \& Eggerman, M. (2014). Caregiver-Child mental health: A prospective study in conflict and refugee settings. Journal of Child Psychology and Psychiatry, 55(4), 313-327.

Sharma, P. P., Jha, A. K., Joshi, A., \& Lamsal, R. (2010). Mass hysteria and adolescent girl: An interventional study. Nepal Journal of Obstetrics and Gynaecology, 5(1), 17-20.

Strekalova, E. \& Hoot, J. L. (2008). What is special about special needs of refugee children?: Guidelines for teachers. Multicultural Education, 16(1), 21-24.

Thabet, A. A. M., Abed, Y., \& Vostanis, P. (2004). Comorbidity of PTSD and depression among refugee children during war conflict. Journal of Child Psychology and Psychiatry, 45(3), 533-542.

Ugurlu, N., Akca, L., \& Acarturk, C. (2016). An art therapy intervention for symptoms of post-traumatic stress, depression and anxiety among Syrian refugee children. Vulnerable Children and Youth Studies, 11(2), 89-102.

UNHCR (2016). Global Report 2016. UNHCR

Wirtz, U. (2009). The symbolic dimension in trauma therapy. In M. Stein (Ed.), Symbolic Life, (pp. 25-52). New Orleans/Los Angeles: Spring Journal. 